\title{
Aspects regarding the improvement of middle schooler attendance at physical education classes
}

Authors' Contribution:

A Study Design

B Data Collection

C Statistical Analysis

D Data Interpretation

E Manuscript Preparation

F Literature Search

G Funds Collection
Dana loana Cristea ${ }^{1}$ ABC, Anca-Cristina Pop ${ }^{1 \text { AFE, Paula Nica }}{ }^{2 B C}$, Aurelian Andrei Cristea ${ }^{3 \mathrm{EF}}$, Gheorghe Lucaciu ${ }^{1} \mathrm{BCD}$, Marius Alin Marinău ${ }^{1} \mathrm{BCE}$

${ }^{1}$ Department of Physical Education, Sport and Physical Therapy, University of Oradea, Oradea, Romania

2 Dinamo Bucharest Sports Club, basketball section, Bucharest, Romania

3 "Greco-Catholic" High school, Oradea, Romania

\section{abstract}

Background: Physical education may be thought of as a special form of education through one's body which aims not only to fulfil biological purposes, but which also entails significant psychological and social issues. Starting from this point, the aim of the present study is to decrease the number of students exempted from physical education classes by asking them to fill in a survey before each class.

Material and methods: The study was conducted in 4 schools from Oradea, over the course of 12 weeks of middle school classes.

Results: A visible result was a decrease in the number of students exempted from physical education by 4 to 6 students. Surprisingly, the number of eighth graders exempted from physical education increased.

Conclusions: Implementing surveys over a longer period of time would lead to significant results with regards to student attendance at physical education classes.

Key words: physical education, middle school, student attendance, participation in PE.

\section{article details}

Article statistics: Word count: 2,440; Tables: 0; Figures: 3; References: 31

Received: June 2021; Accepted: October 2021; Published: November 2021

Full-text PDF: http://www.balticsportscience.com

Copyright @ Gdansk University of Physical Education and Sport, Poland

Indexation: Celdes, Clarivate Analytics Emerging Sources Citation Index (ESCI), CNKI Scholar (China National Knowledge Infrastructure), CNPIEC, DOAJ, EBSCO - Central \& Eastern European Academic Source, EBSCO - SPORTDiscus, EBSCO Discovery Service, Google Scholar, Index Copernicus, J-Gate, Naviga (Softweco, Primo Central (ExLibris), ProQuest - Family Health, ProQuest - Health \& Medical Complete, ProQuest - Illustrata: Health Sciences, ProQuest Nursing \& Allied Health Source, Summon (Serials Solutions/ProQuest, TDOne (TDNet), Ulrich's Periodicals Directory/ ulrichsweb, WorldCat (OCLC)

Funding: This research received no specific grant from any funding agency in the public, commercial, or not-for-profit sectors. Conflict of interests: Authors have declared that no competing interest exists.

Corresponding author: Dana loana Cristea; Department of Physical Education, Sport and Physical Therapy, University of Oradea; email: danacristea07@yahoo.com

Open Access License: This is an open access article distributed under the terms of the Creative Commons Attribution-Non-Commercial-NoDerivatives 4.0 International (https://creativecommons.org/licenses/by-nc-nd/4.0/), which permits use, distribution, and reproduction in any medium, provided the original work is properly cited, the use is non-commercial and is otherwise in compliance with the license. 


\section{INTRODUCTION}

In 2016, throughout the world, $18 \%$ of the children between 9 and 15 were reported to be overweight $[1,2]$, a percentage which increased [3], and which comes along with an increased risk of comorbidities [4] or various health problems [5-7]. On the Internet, one may often find the phrase "children hate sports". However, there are multiple examples of children who did enjoy sports and who dedicated themselves to sports, whatever the type of sports. Should we take gymnastics into account, there is Nadia Comăneci; by the same token, there is Ghiță Mureșan in basketball and Gheorghe Hagi in football [8-10]. But what determined these children to actually enjoy doing sports? How did they connect with sports if not via their first physical education classes? Thus, one may infer that, in the past, Romania had several sportsmen and sportswomen engaged in extracurricular sports activities, who took part in them thanks to their physical education teachers, who, in turn, discovered their skills and led them to greater performance. Nowadays, despite such examples, children refuse to take part in sports and, most of the time, they even refuse to attend physical education classes at school [11-15]. Is it so due to the manner in which these classes are taught, due to their content, or due to each and every person's convenience?

Physical education may be thought of as a special form of education through one's body, which aims not only to fulfil biological purposes, but which also entails significant psychological and social issues [16, 17]. In the 21st century, physical education may no longer be regarded as a subject which supplements the curriculum or as an activity which demands formality and a certain conformity, long since obsolete in the light of current requirements and thought. The evolution of this subject is mainly influenced by the transformation of our society, among which new social and natural factors turn up, these too having a significant impact on one's body. Therefore, the development of a new approach is needed, along with an education and health policy which can adapt to such requirements [18-21].

Introducing such an approach, physical education can become not only a field of study but also a way of life, the basis for a harmonious development both physically and biopsychosocially speaking, being part of the group of formative motor activities [22-24].

Should one think of the role and mission of physical education worldwide, distinct schools of thought may be identified. If in states such as Italy, Spain, or Portugal the concept of physical education is understood literally, then there are states that emphasise health, as in Sweden, or training, as in Germany. Differences between these approaches to physical education include the flexibility of the curricula, the variegated and indicative content, the modern competences strived for, or the purpose of the training process [25].

The Romanian educational programme follows two distinct curricular cycles, the first being the development cycle (3rd to 6th grade) and the second being the observation-guidance cycle (7th to 8th grade, 9th grade). One may thus notice that during the reference period (ages 9 to 15) the students activity includes stages from each developmental cycle [26].

Despite the fact that within physical education and sports classes new and diverse methods and means of reaching the intended aims are employed, some children prefer to not take part in them, relying on momentary medical or personal reasons on the basis of which they are exempt from the said class or for a longer period of time; the latter case is rather isolated, since a medical examiner grants the student a document as proof for the present medical condition. Keeping in mind the age particularities of this period, we consider that attending these classes is of great importance in terms of harmonious physical, but also psychosocial, development. 
Implementation of tasks (a survey) to be carried out (filled in) by the students exempt from middle school physical education and sports class will determine a decrease in the number of exemptions and an increase in class attendance.

The tasks of this study are:

- To uncover the reasons behind absenteeism in physical education and sports classes;

- To notice a decrease in absenteeism in the wake of the implemented surveys;

- To establish absence patterns for certain students;

- To define the rate of absenteeism related to the number of students in the said class;

- To define the rate of absenteeism by school.

\section{MATERIAL AND METHODS}

The study was conducted in 4 schools from Oradea (Romania) and carried out in each school across the 5th, 6th, 7th, and 8th grades, one class for each level.

Over the course of the entire period of study (March 2019 - June 2019), the students exempted from the physical education and sports class were asked to fill in a survey. At the start of the class, surveys were handed out to each exempted student, along with attached guidelines, but with no other information related to their filling in. By means of these surveys, issues related to the physical education class were addressed:

- class topics;

- $\quad$ work groups;

- actual exercises;

- comments from the students who fill in the surveys.

Throughout all of the study, the classes where surveys were implemented stayed the same, with no change in their shape or form. All of the schools where the study was conducted are supplied with a sports hall and proper equipment for the optimal delivery of classes.

All students participating in the research should have the same knowledge basis by the end of each class, as previously presented in this paper. Thus, their training has to be somewhat consistent, even if the timetable depends on each teacher and school.

The study extended over a period of 12 weeks, without counting holiday weeks. Over the course of the entire study, surveys created in advance were handed out to the students exempted from physical education and sports so that they could be filled in along the guidelines. The students were not provided with any additional information in regard to how they should answer the given questions, thus being free to ponder upon the information from the lesson carried out in front of them: what they consider of greatest significance and what sparks their interest. The surveys took an intuitive shape and were not modified throughout the entire study in view of ease of comprehension and access, but also of generating a sense of tediousness among those who got to fill them in several times. At the end of the class, the surveys were collected, without providing any feedback to those who completed them. The surveys were then stored until the end of the study period in order to interpret them and provide an overall view on the number of students who filled them in and, implicitly, who were exempted from the said class.

Starting from the gathered information, we addressed:

- Increasing or decreasing the number of students exempted from a class to the other;

- Comparison with the classes of the same level from other schools;

- The demand that the surveys be filled in by the students;

- Noticing student insight in regard to the array of topics addressed;

- The rate of exemption by sex. 
We divided the 12 weeks in 3 study phases: the first phase from 12.03.2019 until 09.04.2019, the second one during 09.04.2019-21.05.2019, and the third in the period of 21.05.201911.06.2019. It should be noted that the second phase was held during the period of midterms, while the latter in the last weeks of school.

\section{RESULTS}

Fig. 1 displays the dynamics of exemption from physical education class among middle schoolers over the course of the 12 weeks in the three periods of study divided into 3 .

From this point of view, one may notice that the attendance rate does not decrease in the beginning; on the contrary, there is an increase, in the first place, during the second phase. This is due to the fact that, as previously mentioned, students rather focused on midterm subjects. Fortunately, we may notice that in the third phase a higher number of students were much more open towards attending physical education and sports classes. Though the reasoning behind this may most likely be of different grounds, the class requirement of filling in surveys and paying attention to what happened in class was definitely one of them (Fig.1).

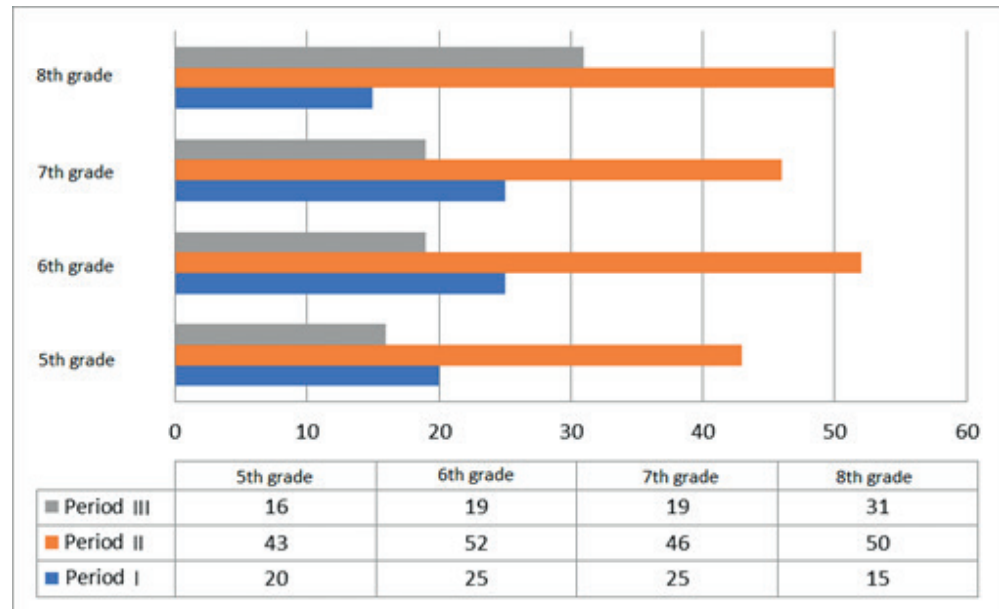

Fig. 1. Evolution of class attendance following survey implementation

The exemption rate by class level suggests that the students in the 5 th grade were exempted in a lower number, by 26.33 compared to older class levels. The 6th and 8th grade present the same rate of 32 students exempted, and in the 7 th grade there is a rate of 30 students exempted (Fig. 2).

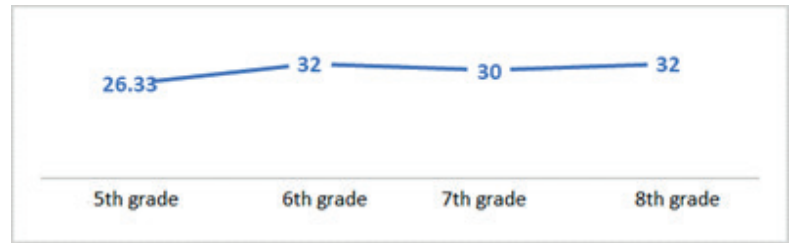

Fig. 2. Average exemption rate by class level

Fig. 3 displays the differences in approach to physical education and sports class by girls and boys. Thus, one may notice that, throughout the entire middle school, girls are exempted in a higher number than boys are. The difference in exemptions between the two sexes in the 5th grade is negligible, whereas, starting with the 6th grade, the difference increases, with a higher number of exempted girls than boys. The prime cause may be 
the precocious development in girls who, at this age, begin to show significant changes in the development of their bodies, physiologies, and personalities (Fig. 3).

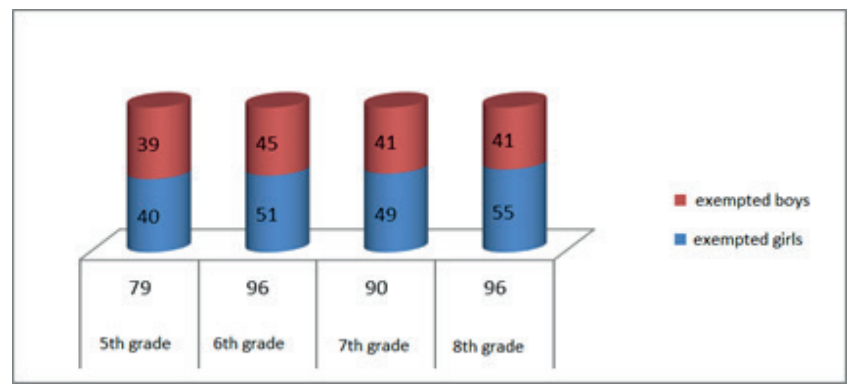

Fig. 3. Number of exempted girl/boys

\section{DISCUSSION}

A difference between the rate of absenteeism at the level of the 5th grade in comparison to the other middle school levels may be noted. This may be due to the two causes discussed also in the theoretical part. The first among these would be the availability of the students towards exercise who, having recently graduated from primary school, where play and motion were employed in most activities, would likely prefer to take an active part in physical education and sports classes. They prefer motion over writing and reading, a factor with notable positive influence onto their attendance at these classes. The other cause would be the accessibility of the curricula for this age group, which allows students to participate and be able to fulfil most of the requirements, without them being embarrassed by individual characteristics, which may be more limited for some of them.

The boom in the number of exempted 6th graders may, too, have several causes. On the one hand, in the case of girls, several physiological and anatomical changes occur, which, in their view, hinder their ability to take part in class. This excuse is often encountered in modern society even though, medically speaking, it cannot be considered a good enough excuse not to exert medium or minimal physical effort, as the one practiced at school. On the other hand, there is the influence of technology over one's willingness to exercise. Most of the time, the 'exempted' students are allowed to play on their phones, which is much more convenient for many of them. Another cause is encountered in the second phase, as previously exposed, namely that, during the period of midterms, students prefer hitting the books for an additional hour, preparing for the subject they will later be examined in, rather than breaking a sweat in the sports class.

7th grade is reported as a rough average of the 5th and 6th grade, with a slightly higher rate of attendance at physical education and sports classes. This may most likely be due to the fact that bonding takes place and, as groups, friendships are created; as a result, students enjoy taking part in activities together.

As expected, 8th grade reports, again, a high number of absentees at physical education and sports classes. This class level will mainly focus on the two subjects they are to be examined in for admission into upper secondary education: Romanian Literature and Mathematics. Unfortunately, neither the students, nor their parents or teachers responsible for these two subjects fully understand the Latin phrase mens sana in corpore sano: a healthy mind in a healthy body. As a result, physical education and sports classes become Romanian Literature or Mathematics classes, or any other subject considered to be of greater importance.

Literature reminds us of the exemptions from physical education in case of sickness and the return to exercise depending on the condition [27]. 
The means of delivering physical education classes should not be neglected either, as a significant role is fulfilled by s specialist teacher. He or she has to constantly seek out ways of boosting the appeal of the class, a consistent adjustment to the students' needs.

\section{CONCLUSIONS}

With the collected data being thus analysed, it may be noted that student attendance at physical education and sports classes fluctuates over the course of middle school. As previously discussed, the causes behind this fluctuation are diverse.

Following the implementation of surveys, a decrease in the number of students exempted from physical education may be noted. In their view, physical education is of lesser importance, as opposed to the subjects that they are to be examined in or the ones they would like to build a career in, which seem to be granted a privileged status. The need for sports in daily life, their value in one's well-being, and not only these, should be reinforced.

The present paper may raise awareness among physical education teachers and raise some questions related to the number of students exempted from classes. By the same token, the need of seeking solutions in regard to increasing the appeal of physical education classes is persistent. This can be improved by the following:

- Holding meetings with children and their parents: these meetings aim to create an awareness in regard to the perks of sports in school and the need to exercise;

- The constant use of these surveys over a longer, undetermined period of time may have a much more positive influence, as an increase in class attendance rate will be noted. This is due to the character of the students who find it easier to take an active part in class, even with an average level of commitment, rather than to constantly focus on the lesson and write down the information provided by the teacher.

- The act of diversifying extracurricular activities by means of outdoors exercise in free time, tourism, and water sports in neighbouring areas would be a major factor in developing habits of physical education exercises performed independently [27-31].

To conclude, we may safely state that the present study was a pilot project aiming for further research development which could render physical education classes more fashionable among the coming generations of students.

\section{REFERENCES}

[1] Chilimoniuk Z, Borkowska A, Chałupnik A, Raksa K, Sobstyl A, Piecewicz-Szczęsna H. The problem of obesity and overweight among children and youth in the world. J Educ Health Sport. 2018;8(9).

[2] Martin A, Booth JN, Laird Y, Sproule J, Reilly JJ, Saunders DH. Physical activity, diet and other behavioral interventions for improving cognition and school achievement in children and adolescents with obesity or overweight. Cochrane Database Syst Rev. 2018 Mar;(3):CD009728. https://doi.org/10.1002/14651858.CD009728.pub4

[3] Antwi F, Fazylova N, Garcon MC, Lopez L, Rubiano R, Slyer JT. The effectiveness of web-based programs on the reduction of childhood obesity in school-aged children: A systematic review. JBI Libr Syst Rev. 2012;10 (42 Suppl):1-14. https://doi.org/10.11124/jbisrir-2012-248

[4] Kansra AR, Lakkunarajah S, Jay MS. Childhood and Adolescent Obesity: A Review. Front Pediatr. 2021 Jan 12;8:581461. https://doi.org/10.3389/fped.2020.581461

[5] Bidzan-Bluma I, Lipowska M, Physical Activity and Cognitive Functioning of Children: A Systematic Review, Int J Environ Res Public Health. 2018 Apr;15(4):800. https://doi.org/10.3390/ijerph15040800

[6] Buhaș R, Săveanu S, Bacter C. Aspects regarding extracurricular sport activities in schools from Bihor County, Romania. 2020;Spec Iss1:36-45. https://doi.org/10.29359/BJHPA.12.Spec.Iss1.05

[7] Herman GV, Banto N, Caciora T, Ungureanu M, Furdui S, Grama V, Buhas R, Buhas S. Tourism in Bihor County, Romania. Trends and Prospects. 2020; Folia Geogr 62, 87-105.

[8] Barbu D. Theory and Practice in High Performance Football. Craiova, Pro Universitaria Publishing House, $2012 ; 113$

[9] Brindescu S, Buda IA. Study on the Efficiency of the Playmaker in Modern Football, In 6th International Conference of Universitaria Consortium "FEFSTIM: Physical Education, Sports and Kinesiotherapy-implications in quality of life". 2020; 13-18.

[10] Brândescu S, Datcu R. Improving motor skills of children in secondary school by using means specific to football game. Timisoara Phys Educ Rehabil J. 2014;7(13:32-38. 
[11] Somerset S, Hoare DJ, Barriers to voluntary participation in sport for children: a systematic review. BMC Pediatr. 2018;18:47. https://doi.org/10.1186/s12887-018-1014-1

[12] Buhaș SD, Herman GV, PF Dragoș PF, Stance L. Football and economy before and after communism in Romania. GeoSport Soc. 2017;6(1):30-39

[13] Buhaș S. Sports and Physical Education - Forms of Socialization. GeoSport for Society. 2015. 3(2), 53-60

[14] Georgescu C, Buhaș R. Aspects regarding extracurricular sport activities in schools from Bihor County, Romania. 2020;Spec Iss1:69 -78. https://doi.org/10.29359/BJHPA.12.Spec.Iss1.08

[15] Ilieș DC, Buhaș R, Ilieș A, et al. Indoor Air Quality Issues. Case Study: The Multipurpose Sport Hall of the University of Oradea.2018; Environmental Engineering \& Management Journal (EEMJ). 2018;17(12):2999-3005.

[16] Bota A, Teodorescu S. Educația fizică - disiplină în planul de învățământ. Bucharest: Discobolul Press; 2010 , 20. [Physical education - discipline in the curriculum]. Romanian.

[17] Buhaș SD, Stance L. The Relationship between Personality and Physical Activity. Geosport Soc. 2017;7(2):72-77

[18] Andrew P Hills AP, Dengel DR, Lubans DR, Supporting public health priorities: recommendations for physical education and physical activity promotion in schools. Progress in Cardiovascular Diseases. 2015;57(4):368-74. https://doi.org/10.1016/j.pcad.2014.09.010

[19] Dragoș P, Lucaciu G, Trifa I, Mirela Ștef Gavriș M, Szabo-Alexi P, Buhaș S. Aspects Regarding the Influence of Communication on the Motivation of Employees in Some Sports Organizations. Proceedings of the 4th International Conference of the Universitaria Consortium (ICU 2018): The Impact of Sport and Physical Education Science on Today's Society. 2018, 73-77.

[20] Dragoș P, Szabo-Alexi M, Szabo-Alexi P, et al. Investigations concerning the influence of sports trainings carried out in a protected area (Natura 2000 site) on various physiological and biological parameters for athletes. Geosport Soc. 2017;6(1):40-46.

[21] Olszewski-Strzyżowski DJ. European societies' access to sport-the European Union actions, GeoSport Soc. 2018;9(2):71-81.

[22] Bailey R. Physical education and sport in schools: a review of benefits and outcomes. J School Health. 2006 Oct;76(8):397-401. https://doi.org/10.1111/j.1746-1561.2006.00132.x

[23] Verity M Booth VM, Rowlands AV, Dollman J. Physical activity temporal trends among children and adolescents. J Sci Med Sport. 2015 Jul;18(4):418-25. https://doi.org/10.1016/j.jsams.2014.06.002

[24] Cristea DI, Sabău AM, Sturzu, Cristea A. Aspects regarding movement combination possibilities to optimize the third part of the physical education lessons Analele Universităţii din Oradea. Fascicula Educaţie Fizică şi Sport. 2019; XXIX.

[25] Zadarko E, Zbigniew B, Szabo-Alexi P, et al. Physical Education and Students' Health Promotion Platform as an Element of European Union's Health Strategy Against the Level of Cardiorespiratory Fitness of Students From Poland, Slovakia, Romania. Studia Universitatis Babes-Bolyai, Educatio Artis Gymnasticae. 2011;56(3):107-116.

[26] Scarlat E., Scarlat M. B. Educație Fizică și Sport [Physical education and sport]. Bucharest: Editura Didactică și Pedagogică; 2002, 27-29. Romanian.

[27] Rozek K, Kwiatkowski S, Tęsiorowski M. Powrót do aktywności fizycznej a długość trwania zwolnień z zajęć wychowania fizycznego po lekkim lub średniociezkim urazie czaszkowo-mózgowym u dzieci w wieku szkolnym [Return to physical activity and duration of exemption from physical education classes after mild and moderate head injury in children at school age]. Przegl Lek. 2014;71(8):433-6. Polish.

[28] Morar C, Pop AC. Water, tourism and sport. A conceptual approach. GeoJTourism Geosites. 2016;2(18):249-258.

[29] Pop AC. Ways of improving tourism via developing Four Cross competition tracks, Analele Universității din Oradea, Seria Geografie. 2012;XXII(2).

[30] Olău Varodi M, Cristea DI, Pop AC, Gozner M. Sport and adventure in the Pădurea Craiului Mountains. Geosport Soc. 2019;11(2):48-58. https://doi.org/10.30892/gss.1101-048

[31] Herman GV, Grama V, Sonko SM, et al. Online Information Premise in the Development of Bihor Tourist Destination, Romania. Folia Geographica. 2020;62(1):21-34. . 